\title{
Planned Closeout of the Cf-252 Loan/Lease Program
}

\section{February 2013}

\author{
Prepared by
}

Steven Sherman

Brad Patton

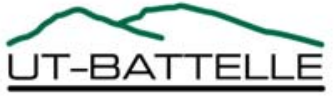




\title{
DOCUMENT AVAILABILITY
}

Reports produced after January 1, 1996, are generally available free via the U.S. Department of Energy (DOE) Information Bridge.

Web site http://www.osti.gov/bridge

Reports produced before January 1, 1996, may be purchased by members of the public from the following source.

\author{
National Technical Information Service \\ 5285 Port Royal Road \\ Springfield, VA 22161 \\ Telephone 703-605-6000 (1-800-553-6847) \\ TDD 703-487-4639 \\ Fax 703-605-6900 \\ E-mail info@ntis.gov \\ Web site http://www.ntis.gov/support/ordernowabout.htm
}

Reports are available to DOE employees, DOE contractors, Energy Technology Data Exchange (ETDE) representatives, and International Nuclear Information System (INIS) representatives from the following source.

Office of Scientific and Technical Information

P.O. Box 62

Oak Ridge, TN 37831

Telephone 865-576-8401

Fax 865-576-5728

E-mail reports@osti.gov

Web site http://www.osti.gov/contact.html

This report was prepared as an account of work sponsored by an agency of the United States Government. Neither the United States Government nor any agency thereof, nor any of their employees, makes any warranty, express or implied, or assumes any legal liability or responsibility for the accuracy, completeness, or usefulness of any information, apparatus, product, or process disclosed, or represents that its use would not infringe privately owned rights. Reference herein to any specific commercial product, process, or service by trade name, trademark, manufacturer, or otherwise, does not necessarily constitute or imply its endorsement, recommendation, or favoring by the United States Government or any agency thereof. The views and opinions of authors expressed herein do not necessarily state or reflect those of the United States Government or any agency thereof. 
ORNL/TM-2012/248

Revision 1

Fuel Cycle and Isotopes Division

\title{
PLANNED CLOSEOUT OF THE CF-252 LOAN/LEASE PROGRAM
}

\author{
Steven Sherman \\ Brad Patton
}

Date Published: February 2013

Prepared by

OAK RIDGE NATIONAL LABORATORY

Oak Ridge, Tennessee 37831-6283

managed by

UT-BATTELLE, LLC

for the

U.S. DEPARTMENT OF ENERGY

under contract DE-AC05-00OR22725 



\section{CONTENTS}

\section{Page}

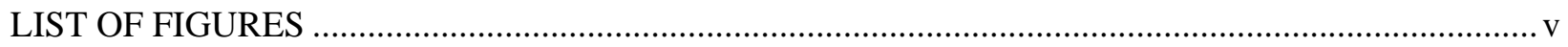

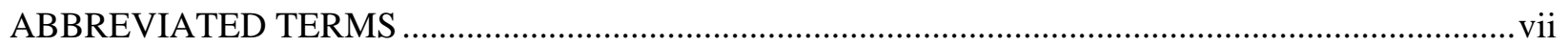

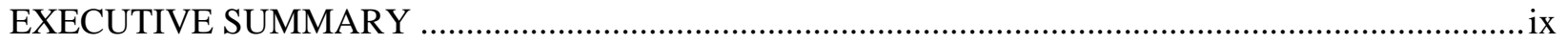

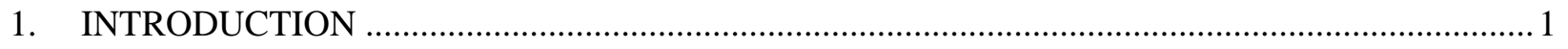

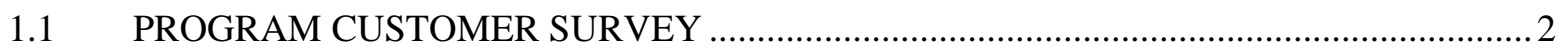

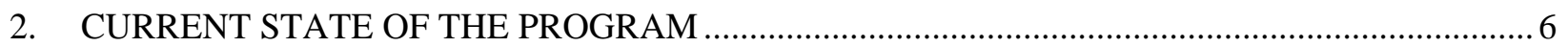

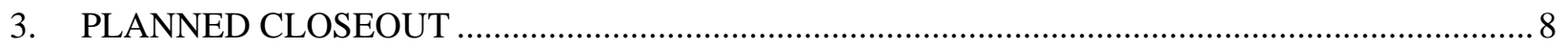

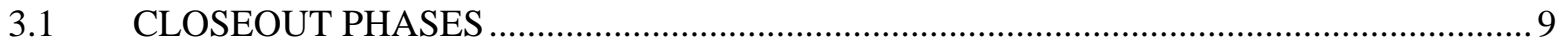

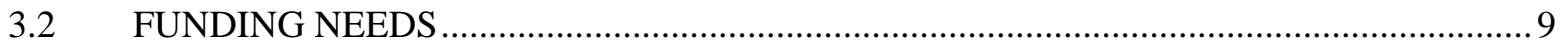

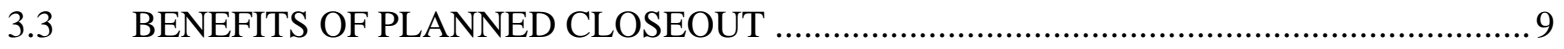

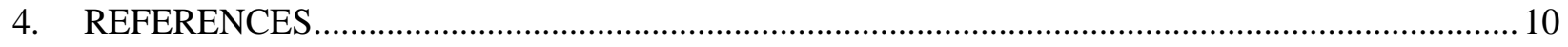





\section{LIST OF FIGURES}

Fig. 1. Example Cf-252 sealed sources........................................................................................ 1

Fig. 2. Current sponsor breakdown for 219 loaned/leased Cf sources..................................................... 4

Fig. 3. Sponsor breakdown for new sources predicted over the next 2 years (53 total). ........................... 4

Fig. 4. Sponsor breakdown for new sources predicted in 2 to 10 years $(77$ total)................................... 5

\section{LIST OF TABLES}

Table 1. List of NRC registration certificates and DOT special form certificates .................................... 6 



\section{ABBREVIATED TERMS}

$\begin{array}{ll}\text { DOE } & \text { U.S. Department of Energy } \\ \text { DOE-EM } & \text { DOE Office of Environmental Management } \\ \text { DOE-SC } & \text { DOE Office of Science } \\ \text { DOT } & \text { U.S. Department of Transportation } \\ \text { HFIR } & \text { High Flux Isotope Reactor } \\ \text { LLW } & \text { low-level radioactive waste } \\ \text { NIDC } & \text { National Isotope Development Center } \\ \text { NNSA } & \text { National Nuclear Security Administration } \\ \text { NNSS } & \text { Nevada National Security Site } \\ \text { NRC } & \text { U.S. Nuclear Regulatory Commission } \\ \text { ORNL } & \text { Oak Ridge National Laboratory } \\ \text { OSO } & \text { DOE Oak Ridge Site Office } \\ \text { PNNL } & \text { Pacific Northwest National Laboratory } \\ \text { REDC } & \text { Radiochemical Engineering Development Center } \\ \text { SRS } & \text { Savannah River Site }\end{array}$





\section{EXECUTIVE SUMMARY}

Oak Ridge National Laboratory (ORNL), on behalf of the U.S. Department of Energy (DOE), is responsible for the Cf-252 Loan/Lease Program and its program assets. This program was previously funded by DOE's Defense Programs (now NA-12). Its inventory includes approximately 335 sources stored on site in Building 7930 and 225 sealed Cf-252 sources at 50 different sites, including other DOE laboratories, universities, and medical institutions. The program is currently unfunded.

In the program's current state, no additional sources may be loaned to program customers, and no source returns can be accepted unless the program customer pays the full cost of the source return. ORNL has requested inactivation of its suite of U.S. Nuclear Regulatory Commission (NRC) certificates of registration to eliminate future licensing fees, and no new sources can be manufactured and issued to NRC-regulated program customers unless the certificates are reactivated. The program has also transferred responsibility for the two U.S. Department of Transportation special form capsule certificates under its control to the ongoing Cf-252 Industrial Sales Program.

ORNL has analyzed various scenarios, from revival of the program to immediate closure, and believes that the best path forward is to close the program in a steady and methodical fashion. Funding in the amount of $\$ 250 \mathrm{~K}$ has been received from NA-73 to perform closeout planning. The concept of program closeout is as follows. The program will not make any new sources. Funding will be used to recall and process all sources out on loan and to dispose of sources that are not needed by other DOE programs. Sources will be recalled to ORNL according to a schedule that is developed in cooperation with program customers. Returned sources and sources stored on site that meet low-level waste (LLW) disposal criteria will be disposed of at the Nevada National Security Site. Sources not meeting LLW disposal criteria will be packaged and disposed of as transuranic waste to the Waste Isolation Pilot Plant. Sources containing significant amounts of Cm-248, Cf-251, and other isotopes of interest will be advertised as available to other DOE programs through the ORNL Isotope Business Office, but will be disposed if no other program takes responsibility for those sources by the time disposal is initiated.

The work will be performed in phases. In the initial phase, program customers will be surveyed to collect information vital to planning the recall schedule. In the second phase, sources will be recalled from nonDOE entities. In the third phase, the remaining sources from DOE entities will be recalled. Initial funding not used during the first phase will be used to initiate the second phase, and additional funding will be sought from NA-73 in future years to perform program closeout.

Performance of a planned closeout of the Cf-252 Loan/Lease Program will reduce and then eliminate any liabilities associated with maintenance of a loaned or leased inventory of radioactive sealed sources that are outside of direct DOE control. The program's inventory of stored sealed sources will also be eliminated, thus preventing them from becoming orphaned. Yearly NRC licensing fees, which cost the program \$93,600 in FY 2012, have already been stopped, and the responsibility for payment of fees related to renewal of the DOT special form certificates in future years has been transferred to the Cf-252 Industrial Sales Program which is funded by industry. Since the manufacture and distribution of new sources is no longer performed, a cost avoidance of \$70 - \$110K (FY 2012 dollars) per new source, not including the cost of Cf-252, is achieved. Lastly, performance of the planned closeout will demonstrate that DOE is a responsible steward of its nuclear energy and materials programs. 



\section{INTRODUCTION}

Oak Ridge National Laboratory (ORNL) manages the Californium-252 (Cf-252) Loan/Lease Program (formerly part of the Cf-252 Market Evaluation Program) on behalf of the U.S. Department of Energy (DOE) and is responsible for its program assets. The Cf-252 Market Evaluation Program began at the Savannah River Site (SRS) in the late 1960s and was created to develop the market for portable Cf-252 neutron sources for applications in neutron radiography, neutron activation analysis, and therapeutic medicine. The Cf-252 Loan/Lease Program was established to provide low-cost access by government agencies, qualified government contractors, and universities to Cf-252 sealed sources for educational, research, and medical applications. Examples of sealed Cf-252 sources are shown in Fig. 1.

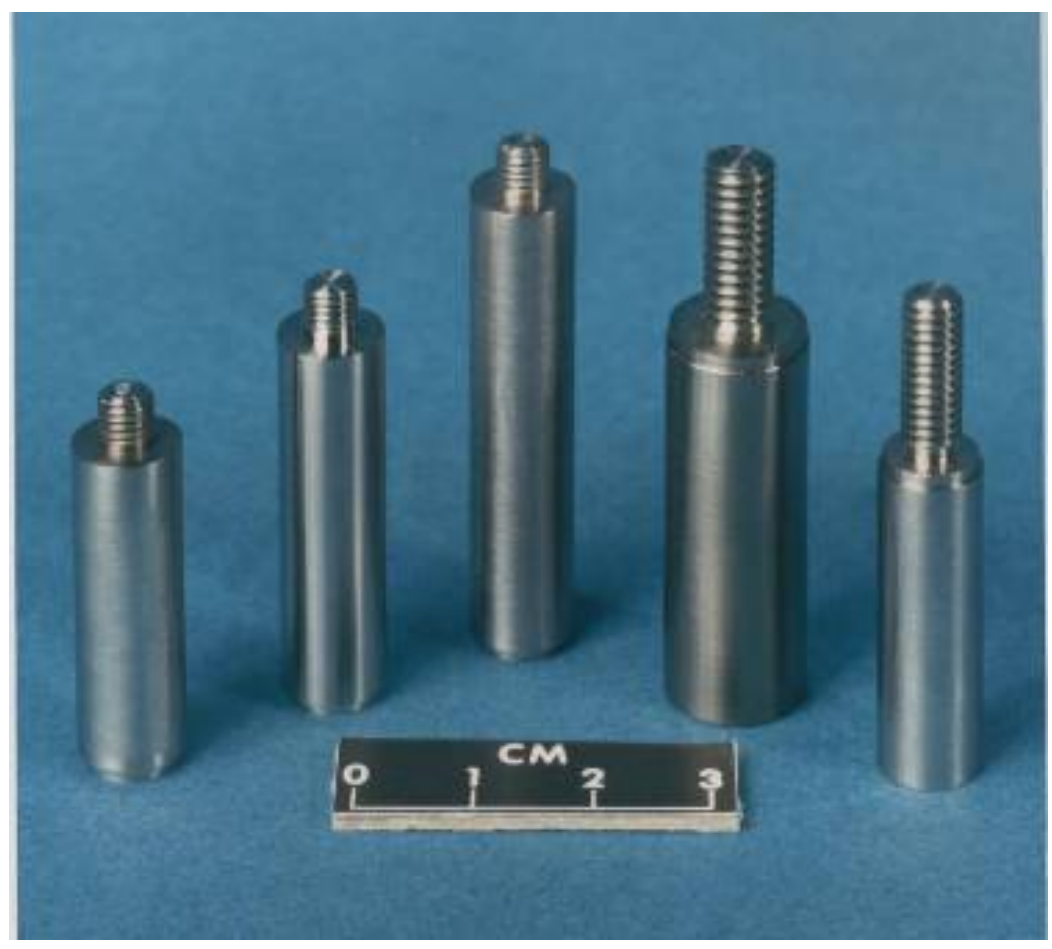

Fig. 1. Example Cf-252 sealed sources.

Production of Cf-252 for the Market Evaluation Program was performed initially in the High Flux Isotope Reactor (HFIR) at ORNL. The isotope was then produced at SRS by a large-scale irradiation of $8 \mathrm{~kg}$ of $\mathrm{Pu}-242$ in 86 Mark 18A targets using a special high-flux configuration in one of the SRS production reactors (the K-Reactor). The latter was called the "Californium-I Campaign" and the Mark 18A targets were sometimes called "Californium-I housings." SRS initiated construction of a large-scale processing facility ("Multipurpose Plutonium Processing Facility") in the warm side of F-Canyon (the less radioactive side of the F-Canyon facility), but construction was never completed. Therefore, in FY 1973, 21 of the irradiated Mark 18A targets were sent to ORNL and were processed in the Radiochemical Engineering Development Center (REDC) to recover Cf-252 from irradiated targets, and the extracted Cf252 was sent back to SRS to be manufactured into sealed sources. The americium and curium recovered from the REDC operations were fabricated into HFIR targets, irradiated, and processed in the REDC to recover additional Cf-252 for SRS. The HFIR/REDC campaigns were repeated several times, and, in total, $2.1 \mathrm{~g}$ of Cf-252 were sent to SRS for use in the Market Evaluation Program (Boswell 2000).

In 1987, the Market Evaluation Program at SRS was shut down, and the source fabrication and distribution program was shifted to ORNL and was centered in REDC Building 7930. Because substantial amounts of Cf-252 were sold to industrial source fabricators and continuing sales were expected, the 
commercial part of the program was separated and renamed the Cf-252 Industrial Sales Program, and the remaining portion of the program was renamed the Cf-252 Loan/Lease Program The Cf-252 Loan/Lease Program was continued for its initial purpose as described above. Loaned sources were returned to the REDC Californium Facility for storage and future loans. Sources fabricated by commercial manufacturers were not accepted for storage/recycle.

The program was funded by the Atomic Energy Commission, the Energy Research and Development Administration, and the DOE Defense Materials Production Program (DP-20, now NA-12) programs from its start until 2008. Sales of Cf-252 to industry were managed by the DOE Isotope Program which collected revenues to pay for production of Cf-252 needed by industrial users, and NA-12 provided funding to pay for the production of Cf-252 needed for its mission. In 2009, NA-12 determined that it no longer needed Cf-252, and it terminated funding for production of Cf-252 and for continuation of the Cf252 Loan/Lease Program. Funding for continuation of the Cf-252 Industrial Sales Program was quickly restored in 2009 vial sales contracts between the DOE Office of Science Isotope Program and a commercial consortium of source manufacturers and industry users, but no other agreements emerged to support continuation of the Cf-252 Loan/Lease Program.

Under the Cf-252 Loan/Lease Program, sealed sources were loaned or leased to users for a period of 1 to 5 years. The user was obligated to protect the sealed source against physical damage and crosscontamination. The user could return a loaned source to ORNL at any time but was expected to return the source at the end of the agreement unless the agreement was renewed. DOE retained ownership of the sealed source and is responsible for its safe and lawful disposition at the end of its useful life.

All sealed sources managed by the program conform to standard design specifications, and five of the six types of sources currently loaned or leased to customers conform to designs that are referenced to U.S. Nuclear Regulatory Commission (NRC) certificates of registration. Two of the six NRC-referenced source types are also covered by U.S. Department of Transportation (DOT) special form certificates. Each sealed source may contain quantities of less than $1 \mu \mathrm{g}$ up to milligram quantities of californium oxide $\left(\mathrm{Cf}_{2} \mathrm{O}_{3}\right)$ in a palladium matrix or californium oxysulfate $\left(\mathrm{Cf}_{2} \mathrm{O}_{2} \mathrm{SO}_{4}\right)$ microspheres in an aluminum matrix. Older sources also contain measureable amounts of $\mathrm{Cm}-248$, which is created by the radioactive decay of Cf-252.

Aside from the Cf-252 Loan/Lease Program, customer demand for Cf-252 sources is met by customer purchase of sealed sources from commercial suppliers. For more information about customer demand for new Cf-252 sealed sources, see Sect. 1.1 below.

\subsection{PROGRAM CUSTOMER SURVEY}

The DOE Office of Nuclear Materials Integration (NA-73) funded a survey of current users in FY 201011. The survey was developed to be completed on line, and emails were sent out to the existing source holders on record. About $70 \%$ of the users responded to the survey.

- Input was received from 46 of 66 users.

- The input represents about 139 of 226 sources (a subset of which are under the control of the Cf-252 Loan/Lease Program).

- $\quad$ Of the 139 sources, 122 were described as needed for future work.

- The users identified the need over the next 2 years for 53 new sources containing collectively an estimated mass of $12 \mathrm{mg}$ of Cf-252 and the need between 2 and 10 years out for 77 sources containing collectively an estimated mass of $19 \mathrm{mg}$ of Cf-252. 
- Most of this work is for, and is sponsored by, the U.S. government (58 of 73 sponsors that were identified).

- The survey did not address the cost of sources, and user responses were based on the assumption that future costs for sources would track historic costs for sources associated with the Cf-252 Loan/Lease Program. The number of new sources desired would be reduced significantly if new users were required to pay commercial prices for new Cf-252 sealed sources.

Based on this input, the sponsor data were grouped into the following categories (see Fig. 2):

- Universities and Hospitals;

- the DOE Office of Science (DOE-SC);

- the National Nuclear Security Administration (NNSA);

- National Security, which encompassed

— the U.S. Department of Defense,

— The U.S. Department of Homeland Security, and

— the DOE Office of Environmental Management (DOE-EM); and

- DOE/Other Federal Users.

About 21\% of the sources are used in education. About one-third of the sources are used in National Security or NNSA projects. DOE-SC accounts for about $17 \%$ of the sources use, and the balance is split among DOE-EM, DOE-Other Programs, and Other Federal Users.

The survey responders were asked to anticipate the need for new sources over the next 2 years. Users predicted the need for 52 new sources. Although the dominant source range is 0.5-100 $\mu$ g of Cf-252, 12 of these new sources are anticipated to contain more than $1 \mathrm{mg}$. Based on the sponsor data, the new source use is depicted in Fig. 3.

The users also identified the need for 76 new sources during the following 8 years. The breakdown for the sponsor data is shown in Fig. 4.

NNSA combined with National Security represents about 36\% of the new source needs for years 2 through 10. The universities have also predicted significant needs in the out-years. However, actual source use by the universities will be a strong function of costs to obtain the sources, as indicated by many of the university responses. 


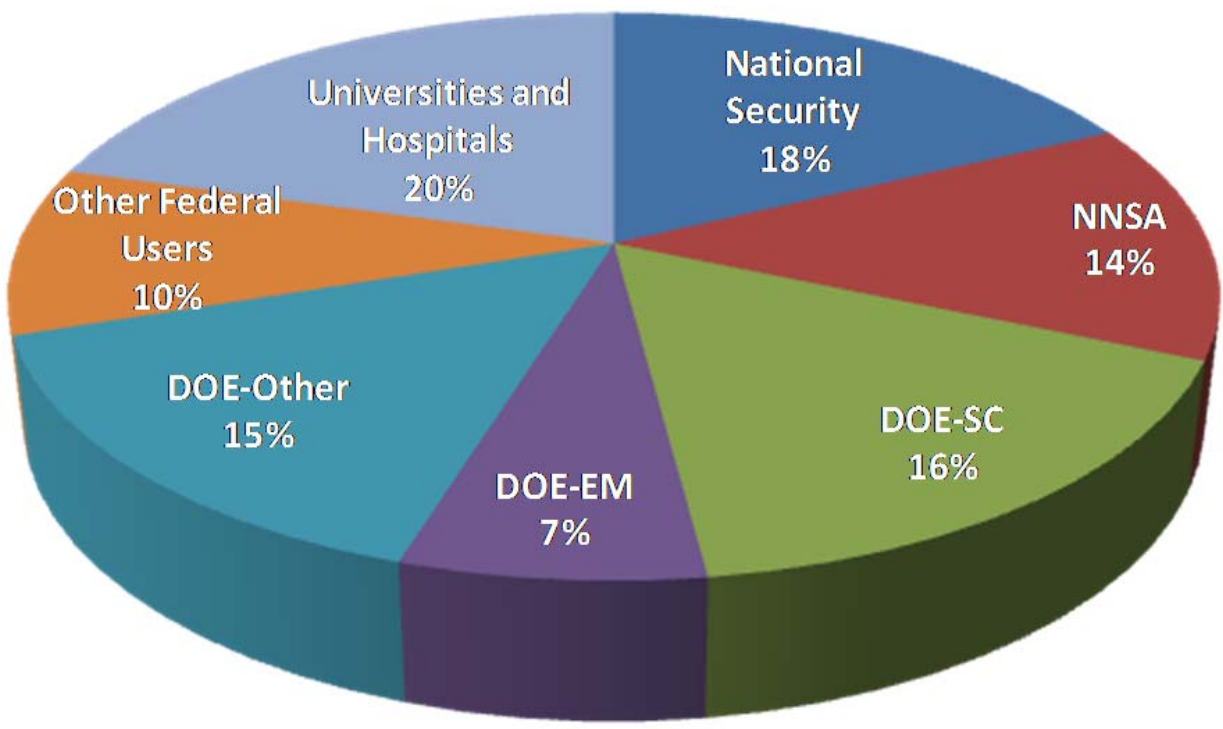

Fig. 2. Current sponsor breakdown for 219 loaned/leased Cf sources.

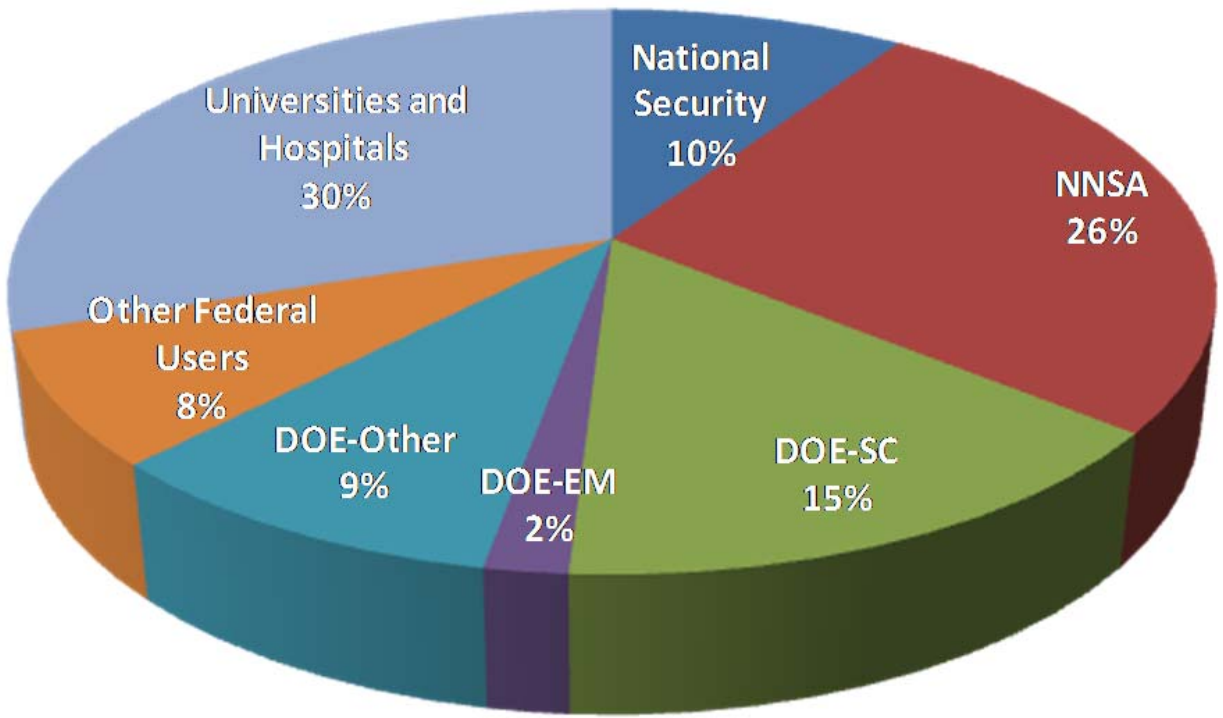

Fig. 3. Sponsor breakdown for new sources predicted over the next 2 years (53 total). 


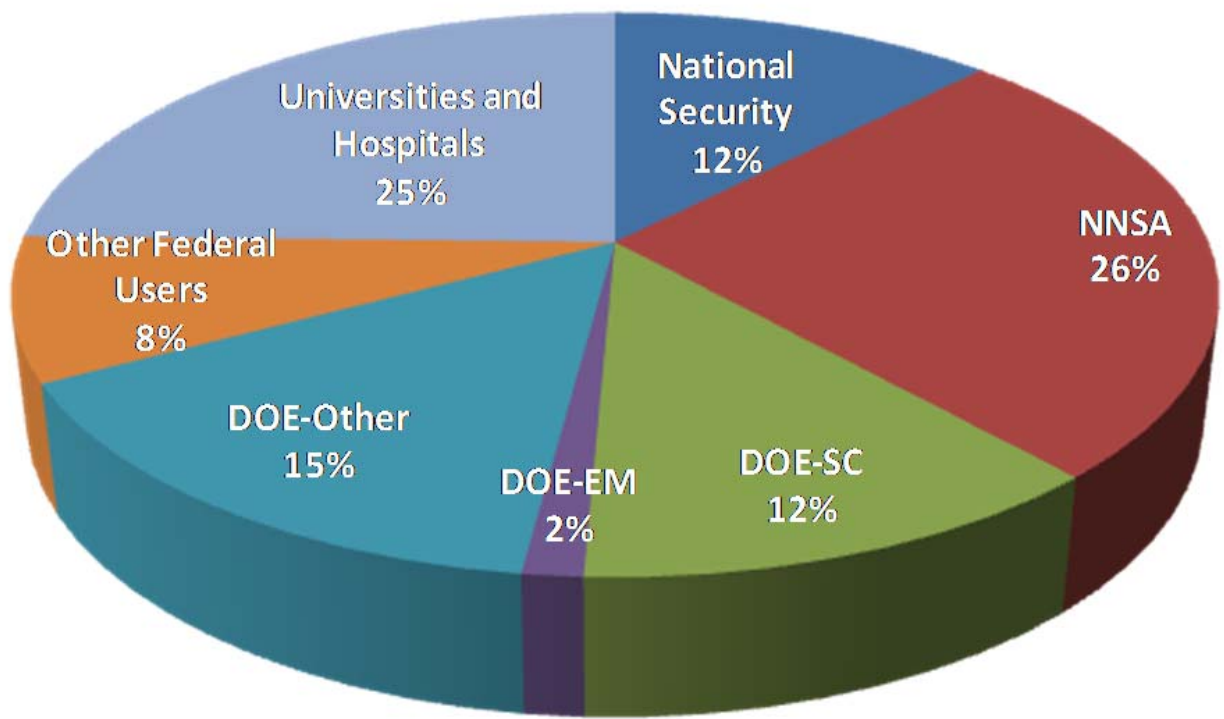

Fig. 4. Sponsor breakdown for new sources predicted in 2 to 10 years (77 total). 


\section{CURRENT STATE OF THE PROGRAM}

The Cf-252 Loan/Lease Program currently lacks a sponsor and is unfunded. In addition, there is a lack of operating funds from the program to cover ORNL costs for storage and maintenance of retired sources. Those costs, though relatively small, are currently being absorbed as ORNL indirect costs.

Due to lack of funding for the Cf-252 Loan/Lease Program, no additional sources may be loaned to program customers, and no source returns can be accepted by ORNL unless the program customer pays the full cost of the source return. ORNL has also ceased manufacture of new Cf-252 sealed sources for the program.

In the short term, the loss of a program sponsor has not yet affected the users to a great extent. Requests for new sources and requests to return sources come infrequently, and most program customers do not know that the program is unavailable. In cases where potential users have sought a new sealed source, they have been referred to commercial suppliers. In cases where a source return was requested, the users have been asked to hold on to the source while program funding issues are being resolved.

In order to avoid future NRC licensing fees, ORNL asked the NRC to inactivate the NRC certificates of registration held by the program. In FY 2012, licensing expenditures totaled $\$ 93,600$ ( $\$ 15,600$ per certificate in FY 2012) which was paid out of residual programmatic carryover funds. The list of NRC certificates of registration is shown in Table 1. Inactivation of the NRC certificates of registration does not make existing sources unsafe or unlicensed, but does prevent the manufacture and release of new sources by ORNL to NRC-regulated customers. The NRC confirmed inactivation of the certificates in December 2012.

Responsibility for the two U.S. Department of Transportation (DOT) special form certificates (Special Form Certificates of Competent Authority, see Radioactive Material Regulations Review 2008) maintained by the program has been transferred to the ongoing Cf-252 Industrial Sales Program. These special form certificates allow for transport of the affected source types to and from customers outside of the United States. Stewardship of these special form certificates by the Cf-252 Industrial Sales Program will ensure that they are maintained regardless of the status of the Cf-252 Loan/Lease Program. The list of DOT special form certificates is also provided in Table 1.

Table 1. List of NRC registration certificates and DOT special form certificates

\begin{tabular}{clc}
\hline \multicolumn{1}{c}{ Certificate \# } & \multicolumn{1}{c}{ ORNL designation } & Expiration date \\
\hline & \multicolumn{1}{c}{ NRC registration certificates } \\
NR-0277-S-101-S & AT, SALC, ALS, Type N series & \\
NR-0277-S-102-S & USS, ULS series & $9 / 30 / 2012$ \\
NR-0277-S-103-S & SRNL Model ALC-PXC series & $9 / 30 / 2012$ \\
NR-0277-S-104-S & SR-Cf-100 series, SR-Cf-1 series & $9 / 30 / 2012$ \\
NR-0277-S-106-S & SR-Cf-3000 series, OR-Cf-3000 series & $9 / 30 / 2012$ \\
NR-0518-S-101-S & NSD series, NZD series & $9 / 30 / 2012$ \\
& DOT special form certificates & $9 / 30 / 2012$ \\
USA/0018/S-96 & SR-Cf-100 series & \\
USA/0236/S-96 & SR-Cf-3000 series & $9 / 30 / 2015$ \\
\hline
\end{tabular}


In the longer term, the consequences of leaving the Cf-252 Loan/Lease Program unfunded are more severe. Administrative control over existing sealed sources will erode, and information on those sources may become inaccurate or lost over time. Loaned sources would become stranded at customers' locations with customers who may not have the expertise, funding, or regulatory authority to dispose of those sources properly. Many of the sources have no disposal path except at facilities operated by DOE, and DOE would likely have to take responsibility for those sources eventually anyway at potentially higher cost. DOE may also suffer property losses due to loss of the potential salvage value of the californium and curium isotopes contained within the sealed sources. Also, trust in DOE may also be damaged because DOE would not be living up to its commitment to manage responsibly its inventory of radioactive sources (see DOE-IG/0813, 2009). 


\section{PLANNED CLOSEOUT}

The Cf-252 Loan/Lease Program should be closed out in an orderly manner. No new loan or lease agreements will be executed. No new sealed sources will be manufactured for the purpose of loans or leases, and program customers will be referred to commercial suppliers in order to meet demand for new Cf-252 sealed sources. The NRC certificates of registration formerly maintained by the program will remain inactivated, and the DOT special form certificates will remain under the control of the Cf-252 Industrial Sales Program. All sources held by program customers will be recalled to ORNL. All returned sources and sources currently stored in the 7930 storage pool that meet low-level waste (LLW) disposal criteria will be disposed to the LLW disposal site at the Nevada National Security Site (NNSS). Returned or stored sources not meeting LLW criteria will be disposed of at the Waste Isolation Pilot Plant (WIPP).

In some cases, sources managed by the program may contain significant amounts of isotopes that are of scientific interest (i.e., Cf-251, Cf-252, and/or Cm-248). These will be advertised as available to other DOE programs through the ORNL Isotopes Business Office, but will be disposed if no other DOE program takes custody for those sources by the time disposal is initiated.

Sources will be recalled according to a schedule. Since ORNL is not prepared to process source returns from all program customers at one time, the recall schedule will be ordered according to customer need, source risk, availability of ORNL personnel to handle source returns, and funding.

At the end of closeout, no sealed source owned by DOE will remain out on loan. All loan and lease agreements will be closed, and all program business records will be archived. All sources having no value to other DOE programs will have been disposed to the NNSS (see DOE/NV-325-Rev.8-01) or WIPP, and responsibility for sources retained in the Building 7930 storage pool will have been transferred to other DOE programs. DOE will no longer be in the business of loaning or leasing low-cost Cf-252 sealed sources.

Within the pool of DOE customers, there may be an opportunity to transfer ownership of sources without having to first return the sources to ORNL for processing if the DOE customer wants to retain possession of sources they hold. In such cases, the ORNL Isotopes Business Office (IBO), with support from DOE Oak Ridge Site Office (OSO), would investigate transferring ownership of the sources from ORNL to the program customer.

There are unanswered questions concerning how a transfer of ownership might be achieved, however. There are no provisions in the loan or lease agreements for the purchase of loaned sources, although users are required to pay ORNL for the residual value of a source if a source is lost or damaged under the current loan/lease agreement. If no significant residual value remains in the loaned sources, then the sources are considered waste, and DOE cannot transfer responsibility for waste disposal to the customer. The most equitable path forward for DOE and the program customer in such cases may be a negotiated sale of the sealed sources, and this would need to be handled on a case-by-case basis. In such cases, it is expected that the ORNL IBO with support from DOE OSO would negotiate the transaction.

ORNL personnel will work closely with the IBO to contact and survey all program customers and to update program records. In addition, help will be sought from ORNL's Legal Directorate to better define customers' and DOE's obligations in regard to loan contract closeouts. 


\subsection{CLOSEOUT PHASES}

The work will be performed in phases. In the first phase, program records will be examined, customers will be told that the program is ending, and information will be collected from program customers concerning their loaned or leased sources. Also, a preliminary recall schedule and cost estimate will be assembled. In the second phase, sources on the recall list will be recalled from non-DOE entities, and source ownership transfers for all program customers (non-DOE and DOE customers alike) will be processed. In the third phase, the sources from DOE entities will be recalled.

In an initial analysis of the closeout project, Phase One will require between 8 and 12 months to complete, while Phases Two and Three combined may require up to 8 years. Efforts will be made during Phase One to construct source recall schedules that reduce the duration of closeout in order to reduce costs.

\subsection{FUNDING NEEDS}

Initial funding of \$250K in FY 2013 has been received from NA-73 to perform closeout planning. Residual carryover funds from Phase One will be used to initiate source returns during Phase Two, and additional funding will be sought from NA-73 to complete the remainder of the source returns and disposal. The amount of funding needed to perform full closeout will be defined during Phase One.

\subsection{BENEFITS OF PLANNED CLOSEOUT}

Performance of a planned closeout of the Cf-252 Loan/Lease Program will reduce and then eliminate any liabilities associated with maintenance of a loaned or leased inventory of radioactive sealed sources that are outside of direct DOE control. The program's inventory of stored sealed sources will also be eliminated, thus preventing them from becoming orphaned. Yearly NRC licensing fees, which cost the program \$93,600 in FY 2012, have already been stopped, and the responsibility for payment of fees related to renewal of the DOT special form certificates in future years has been transferred to the Cf-252 Industrial Sales Program which is funded by industry. Since the manufacture and distribution of new sources is no longer performed, a cost avoidance of \$70 - \$110K (FY 2012 dollars) per new source, not including the cost of Cf-252, is achieved. Lastly, performance of the planned closeout will demonstrate that DOE is a responsible steward of its nuclear energy and materials programs. 


\section{REFERENCES}

Boswell. 2000. James M. Boswell, “Reactor Production Diversity”, WSRC-MS-2000-00061, Proceedings of Symposium: 50 Years of Excellence in Science and Engineering at the Savannah River Site, May 17, 2000, Westinghouse Savannah River Company, pages 99-108.

DOT. Radioactive Material Regulations Review. December 2008. U.S. Department of Transportation, Pipeline and Hazardous Materials Safety Administration.

DOE. 2009. Audit Report: The Department's Management of Nuclear Materials Provided to Domestic Licensees. DOE/IG-0813. February 2009.

DOE. 2011. Nevada National Security Site Waste Acceptance Criteria. DOE/NV-325-Rev.8-01. U.S. Department of Energy, National Nuclear Security Administration, Nevada Site Office, Waste Management Project, January 2011. 